\title{
COMPARATIVE ANALYSIS OF THE THERAPY OF ACUTE TRANSVERSE MYELITIS
}

\author{
By M. Nikolić, Ph.D. and Z. Lević, Ph.D. \\ University Hospital for Neurology and Psychiatry, Belgrade, Yugoslavia
}

Abstract. Three methods of treatment of acute transverse myelitis are presented. The first group of $\mathrm{I} 6$ patients were treated with antibiotics (average age $32 \cdot \mathrm{I}$ ). Three patients died, II remained unrecovered, while in two cases remarkable improvement was recorded. The second group of I 5 patients, whose average age was $32 \cdot 4$, were treated with corticosteroids per os or instrumuscularly. Four of the patients died (three of them with ascendent course of disease), there was no change in five cases, while marked improvement ('cured' and 'walking with assistance') was recorded in the remaining six cases. The third group of ten patients, eight women and two men, ranging from 15 to 47 years of age (average age $26 \cdot 9$ ) was treated with methylprednisolone acetate intrathecally. Five patients were practically cured after 3 to 4 weeks. Two patients were cured to an extent that they could walk with assistance. In two cases no improvement was recorded, while one of the patients, who in addition suffered from serum myelitis, died of bilateral bronchopneumonia. In all these cases the drug was administered comparatively late, on the 6 th or 7 th day of the disease.

Key words: Acute transverse myelitis; Corticosteroids; Methylprednisolone acetate.

\section{Material and Methods}

THE analysis included 4I patients suffering from ATM who underwent treatment at the Neuropsychiatric Clinic in Belgrade. The principal diagnostic criteria were the following: febrile beginning, onset of acute transverse symptomatology, leucocytosis and accelerated SE, and pleocytosis and increase of protein in liquor. All patients showed acute transverse symptomatology. Previous to or at the onset of the illness 33 patients had increased temperature, 3I had leucocytosis and/or accelerated SE, while 23 patients showed changes in the cerebrospinal fluid. All of these four conditions were recorded in 23 patients. Three patients developed ascending progress of the illness.

In 35 patients the aetiology was unknown, while in the remaining six it could be associated with bacterial sepsis (I), paranephritic abscess (I), antitetanus serum (I), viral myocarditis (I) and active pulmonary tuberculosis (2).

According to the method of treatment, the patients were divided into three groups. Sixteen of the patients were treated with antibiotics without corticosteroids (group I), I5 were given corticosteroids orally or intramucularly (group 2), while ten patients received methylprednisolone acetate intrathecally (group 3). The age and sex of the patients are shown in Table I.

TABLE I

\begin{tabular}{|c|c|c|c|c|}
\hline Group No. & $M$ & $\mathrm{~F}$ & Age & Average \\
\hline I & IO & 6 & II -59 & $32 \cdot I$ \\
\hline 2 & 9 & 6 & $5-68$ & $32 \cdot 4$ \\
\hline 3 & 2 & 8 & I5-47 & $26 \cdot 9$ \\
\hline
\end{tabular}


Methylprednisolone acetate was applied intrathecally in doses of I.5 to $3 \mathrm{mg}$ per kg of body weight, depending on the gravity of the condition, immediately after a patient's admittance to the hospital. Three or four days later the injection was repeated with half the original dose, and in general three to four injections sufficed. With regard to protection from secondary infection the patients were given broad-spectre antibiotics, and in some cases corticosteroids were added by mouth or intramuscularly.

\section{Results}

The results are described as 'cured', 'walking with assistance', 'no change' and 'death'. We regarded as cured patients who either completely recovered or showed some minimum sequelae (mild spasticity, positive Babinsky sign, urgency of micturition). The second group included patients whose condition had improved inasfar as it enabled them to walk with assistance followed by improved sensibility and improved sphincter function. The results of treatment are shown in Table II.

The group which was treated with antibiotics without corticosteroids showed satisfactory results (cured and walking with assistance) in 12.4 per cent; no change was recorded in 68.7 per cent, while 18.9 per cent deceased. The percentage of cured patients and those of marked improvement rises with oral or parenteral application of corticosteroids-it amounts to 40 per cent, while it is particularly high in cases of intrathecal application of methylprednisolone acetate -70 per cent.

All patients with an ascending progression of the illness died. They were given corticosteroids by mouth or intramuscularly.

The effects of the application of methylprednisolone acetate appeared very soon, either several hours or days after the first injection. Muscular strength improved together with sensibility and sphincter function. In five cases complete cure was achieved only after several weeks. One female patient aged i 5 years to whom the drug was applied only on the I Ith day of the disease, was able to walk with assistance 2 months later. After several more months of physical therapy motility improved to such an extent that she was able to walk without assistance. In another case (male, aged 47) the drug was administered on the 2 nd day of the illness but the recovery was nevertheless slow and took about 2 months. In this case, there were indications that lumbar-sacral roots had been damaged. In two cases (aged 30 and 47) the treatment produced no effect. One of them suffered

TABLE II

\begin{tabular}{|c|c|c|c|c|c|c|}
\hline & \multicolumn{2}{|c|}{ Group I } & \multicolumn{2}{|c|}{ Group 2} & \multicolumn{2}{|c|}{ Group 3} \\
\hline & No. & $\%$ & No. & $\%$ & No. & $\%$ \\
\hline $\begin{array}{l}\text { Cured } \\
\text { Walking with }\end{array}$ & I & $6 \cdot 2$ & 2 & $13 \cdot 3$ & 5 & $50 \cdot 0$ \\
\hline assistance & I & $6 \cdot 2$ & 4 & $26 \cdot 6$ & 2 & $20 \cdot 0$ \\
\hline No change & I I & $68 \cdot 7$ & 5 & 33.5 & 2 & $20 \cdot 0$ \\
\hline Death & 3 & 18.9 & 4 & $26 \cdot 6$ & I & $10 \cdot 0$ \\
\hline Total & I6 & $100 \cdot 0$ & 15 & $100 \cdot 0$ & IO & $100 \cdot 0$ \\
\hline
\end{tabular}


from acute, probably viral myocarditis. In these cases the drug was administered comparatively late, on the 6 th and 7 th day of the illness respectively. One patient from this group (aged 36 ) died 2 months after the beginning of serum myelitis with bilateral bronchopneumonia and severe anaemia. There was no improvement of neurological signs despite a massive dosage of methylprednisolone acetate $(200 \mathrm{mg}$ ) applied intrathecally on the 6th day of the illness.

Prognosis of patients with progressed age was less favourable.

\section{Statistical Assessment}

The chi-square test was used. The difference between the first and second and the second and third groups is not significant. However, the difference between the group which was treated by methylprednisolone acetate intrathecally and that which was treated by antibiotics alone is highly significant $(P<0.005)$.

\section{Comment}

There is a lack of precise data on the incidence of acute transverse myelitis (ATM). Some data only indirectly point to this form of morbidity. According to Buchan et al. (1972), patients suffering from multiple sclerosis and encephalomyelitis, ATM accounts for 8.7 per cent of paraplegiae. In a group of 3000 cases admitted to Stoke Mandeville Spinal Injury Centre, cases of transverse myelitis accounted for 5.3 per cent (Guttmann, 1967). Moreover, there are not many studies on therapy and prognosis of ATM. Before the introduction of antibiotics and the use of respirators, Ioo per cent death rate was to be expected (Lipton \& Teasdall, I973). Since the introduction of antibiotics one-third of the patients were recorded as satisfactory recovery, one-third was described as sufficiently recovered, and one-third as poor (Altrocchi, I963; Lipton \& Teasdall, I973). There is also a lack of information in the literature on the significance of the effects of steroids in the therapy of ATM. Géraud et al. (1964) treated one case of ATM and one case of myelitis caused by herpes zoster virus infection by applying hydrocortisone acetate intrathecally, no effect was found. We are not aware that so far methylprednisolone acetate has been applied intrathecally in the therapy of ATM.

Judging from our experience the introduction of antibiotics has greatly reduced mortality but the percentage of severe disability after the acute stage of treatment remains high (68.7 per cent). The introduction of corticosteroids is another step towards a more successful treatment of this serious disease. If we exclude the patients with the ascending progression and fatal outcome of the disease from the group of patients treated with corticosteroids by mouth or intramuscularly, the difference between this group and that treated without corticosteroids becomes statistically significant $(\mathbf{P}<0.05)$.

Application of methylprednisolone acetate intrathecally offers even more hope for recovery. When the drug was applied during the first 48 hours after the onset of the disease, very good results were obtained in all cases. In the three failures which were recorded, it would appear that the drug was administered too late-6 to 7 days after the beginning of the disease when most probably irreversible changes of the neural elements of the spinal cord had already taken place. One of the patients suffered in addition from viral myocarditis, while in another case the disease was complicated by staphylococcae sepsis. One patient from this group 
whose disease ended fatally, had serum myelitis. We were surprised by the failure of the therapy, despite powerful doses of steroids applied intrathecally.

In experiments performed on cats Lehrer et al. (1973) showed that radioactive methylprednisolone acetate rapidly proceeds to the tissues of the central nervous system where it reaches a five to ten times higher level that can be achieved from other points. It may be assumed that the drug has a direct effect on the inflamed nervous tissue, reducing oedema and hyperaemia, thus preventing irreversible damages of the nervous tissues. It also acts directly upon the meninges and spinal roots which are usually affected by the inflammatory processes. In two female patients a subarachnoidal bloc was found at the lumbar puncture. When the puncture was repeated several days later following injection of methylprednisolone acetate the spinal canal was free, which led us to the conclusion that the block was caused by an oedema of the spinal cord which had disappeared as an effect of the drug. Therefore, the drug reduces the acute danger caused by the inflammation and perhaps also of allergic changes in the spinal cord, thus promoting the defence mechanisms to overcome the pathological process. This drug rarely produces undesirable effects, and those that do occur are never of such nature as to require the therapy to be discontinued.

The younger the patients the more favourable the prognosis regardless of the method of treatment applied.

All patients who were treated with methylprednisolone acetate intrathecally have been under control since. No relapse has been recorded.

\section{Conclusions}

Transverse myelitis is a most serious disease of spinal cord, which had a rate of mortality as high as IOO per cent before introduction of antibiotics.

The introduction of antibiotics has greatly reduced mortality but the percentage of severe disability remains high (68.7 per cent).

Application of corticosteroids represents a step towards a more successful treatment of ATM. Marked improvement in the group of patients treated in this way was recorded in 40 per cent, while the percentage of invalidism was 33 .

The introduction of methylprednisolone acetate intrathecally makes a new therapeutic approach to ATM. Seventy per cent treated in such a way showed marked improvement. The drug must be given as soon as possible in a sufficient dose.

In cases with ascending course of disease, unfortunately, no successful treatment was found.

\section{RÉsumÉ}

Inflamation aigue de la moelle represente une maladie grave, laquelle avant la thérapeutique avec les medicaments antibiotique terminait mortelement.

Introduction des antibiotiques en thérapeutique des myelites a sensiblement reduit la mortalité, mais le pourcentage de l'invalidité est resté, selon notre experiance, trés haut $(68.7 \%)$.

La thérapeutique avec les corticosteroids est le pas suivant vers la progrés de traitement de l'inflamation aigue de la moelle. Une amélioration trés nette de $40 \%$ nous avons noté dans une groupe traiteé par les corticosteroids. Le pourcentage de l'invalidité été 33.

L'introduction intratecale de la methylprednisolone acetate represente une nouvelle amélioration dans le traitement des inflamations aigue de la moelle. Septante pourcentage des malades traitées par cette méthode, a démontré une amelioration trés nette. Le médicament doit être apliqué trés tôt et d'une posologie sufisante. 
Chez les cas des malades qui ont un dècours ascendante nous n'avons pas aucan succé thérapétique.

\section{ZUSAMMENFASSUNG}

Es werden drei Behandlungsarten der akuten Querschnittsmyelitis beschrieben. Die erste Gruppe von I6 Kranken mit durchschnittlichen Lebensalter von Jahren 32. I, wurde mit Antibiotika behandelt. Drei Kranke starben, keine Besserung zeigten II Kranke und eine merkliche Besserung 2 Kranke. Die zweite Gruppe von I5 Kranken mit durchschnittlichen Lebensalter $(32 \cdot 4 \mathrm{~J})$ wurde mit Kortikosteroiden peroral oder intramuscular behandelt. Vier Kranken starben, mit dem aszendierenden Verlauf, ohne Besserung waren 5 Kranke, bei den übrigen 6 wurde wesentliche Besserung (vollständinge Wiederherstellung oder Gehen mit fremder Hilfe) registriert.

Die dritte Gruppe enthielt IO Kranke, 8 Frauen und 2 Männer, im Lebensalter zwischen I5 und $47 \mathrm{~J}$, (durchschnittlich 26.9) die mit der intrathekalen Injektion der Methyl-prednisolon Acetat behandelt wurde. Bei 5 Kranken trat prakisch vollständige Wiederherstellung nach 3-4 Wochen ein. Bei zwei Kranken reichte die Besserung bis zun Gehen mit Unterstützung. Bei zwei Kranken blieb die Behandlung ohne Effekt und der Eine, der an Serummyelitis litt, starb an dopperseitiger Bronchopneumonie, In allen diesen Fällen wurde die Behandlung relativ eingeführt, am 6-7 Tag nach Krankheitsbeginn.

\section{REFERENCES}

Altrocchi, P. H. (1963). Acute transverse myelopathy. Arch. Neurol. 9, I I I.

BoINES, G. J. (I96I). Remissions in multiple sclerosis following intrathecal methylprednisolone acetate. Delaware Med. F. 33, 230.

Buchan, A. C., Fulford, G. E. et al. (I972). A preliminary survey of the incidence and aetiology of spinal paralysis. Paraplegia, 10, 23.

Géraud, J., Dussert, J., Benazet, J. \& Demoures, J. M. (1964). Indications et résultats de l'acétate de méthyl 6 delta I hydrocortisone par voie intra-rachidienne dans la pratique neurologique. Thérapie, 19, 657.

GutTMANN, L. (1967). History of the national spinal injuries centre, Stoke Mandeville Hospital, Aylesbury. Paraplegia, 5, II5.

LeHrer, G. M., Howard, S. M. \& SUlamith, W. (1973). Brain uptake of methylprednisolone acetate. Arch. Neurol. 28, 324 .

Lipton, H. L. S Teasdall, R. D. (I973). Acute transverse myelopathy in adults. A follow-up study. Arch. Neurol. 28, 252.

SEHGAL, A. D. \& GARDNER, W. J. (I960). Corticosteroids administered intradurally for relief of sciatica. Cleveland Clin. Quart, 27, 198. 